\title{
Research on Practical Teaching for Human Resource Management Major
}

\author{
Chenlei Mao \\ Jiangxi University of Technology, 330098 Nanchang, China \\ humao120@qq.com
}

Keywords: Human Resource Management; Major; Practice Teaching

\begin{abstract}
Practice teaching is very important for improving the quality of professional training of human resource management and enhancing the theory teaching effect of human resource management. However, due to the weak teaching practice of teachers, backward teaching concepts, higher difficulty of organization reasons for practice teaching, teaching practice is still a weak point in many professional teaching of human resource management in colleges and universities. To strengthen practice teaching of human resource management major, colleges and universities must establish and perfect the management system of practical teaching, strengthen practice teaching management, build a high level of teaching staff, establish practice teaching platform of human resource management major, establish cooperative education for training of personnel policies and regulations, and improve the industrial and business circles in the talent cultivation in sense of responsibility.
\end{abstract}

\section{Introduction}

Practice teaching is the essential supplement to the traditional theory teaching, which is the essential step for students from the knowledge to the practice, and then to the knowledge and the combination of the knowledge, which is the key point of the cultivation of the comprehensive quality of the talents. In recent years, increasing the education community's attention to the teaching practice, research of teaching practice becomes more and more urgent, especially for human resource management major. How to strengthen the practical teaching, and to improve the training quality of human resource management major, is an important and urgent task for the undergraduate teaching of human resource management in colleges and universities.

\section{The Significance of Practical Teaching for Human Resource management}

In recent years, the development of higher education in China has changed. For most colleges and universities, especially for local colleges, the goal of the talents cultivation has been transformed from the training of academic talents to the special talents who meet the needs of society. This means that the graduates of colleges and universities only have a strong practical ability to adapt to the social and economic development as well as the needs of the talent market. On the other hand, from the point of view of the professional characteristics, human resource management major is a very practical major, graduate students of human resource management not only need to have a solid theoretical foundation, but also have strong ability to solve practical problems faced by the enterprises. Therefore, the process of teaching of human resource management major must attach importance to the training of students operating skills and management skills, through the establishment of the system of practice teaching system, in order to train students' practical ability. 
However, due to a relatively short period of time of human resource management major, curriculum system, teaching method and practice link design of human resource management major in colleges and universities are still in the exploration. The talent cultivation mode of human resource management major in most colleges and universities still pay attention to theory and neglect practice, pay attention to qualitative and neglect quantitative, pay attention to concept and neglect method. This mode of education has been unable to meet the needs of the community for the compound and applied talents, resulting from serious disconnection between supply and demand of talents. Practice teaching is the effective way to get rid of education predicament of human resource management, which can provide diverse practice platform, enable students to deepen of professional the ory knowledge and understanding at the same time, improve the ability of independent thinking and processing, high professional skills and the ability to innovate. Therefore, whether it is from the professional characteristics or from the perspective of social needs, strengthen practice teaching of human resource management major and build a perfect system of practical teaching, which is very necessary and meaningful.

\section{Basic Principles of Practical Teaching for Human Resource Management}

In order to achieve the goal of practice teaching of human resource management, professional human resource management needs system thinking and arrangements in the practice of teaching settings, practice teaching and practice teaching resources and equipment configuration, and other aspects. Follow the basic rules of teaching, distinguish each teaching stage of the practice focus, so that gradually, and gradually improve the practical skills of students. In view of the characteristics of practical teaching, human resource management major must adhere to the following basic principles when practice teaching.

Combination of theory and Practice. Theory comes from practice, and has the guidance to the practice. Theoretical teaching and practical teaching are inseparable two aspects of teaching activities in different stages of teaching activities. In the beginning of the course teaching, the teacher first necessary elaborate theory and pave the way, then students need participate in practice aspects of interaction, the theory has been applied and sublimation. Teaching activities should be based on teaching theory, practice teaching in the theory of teaching activities. In the course system and professional teaching system design, the theoretical teaching and practical teaching should be fully reflected.

Systemic and holistic. Practical teaching is composed of many simulation teaching activities and practical activities, which should become the whole of organic connection. In recent years, formulation of practical teaching has changed from initial "practice teaching" for "practical teaching system". Research on practice teaching tends to be overall and systematic. Major in human resource management in the design practice, the teaching activities should be more from the perspective of system and the overall cut, pay attention to all aspects of the mutual influence, mutual penetration and mutual contact and building practice teaching system for the goal of training according to human resource management major.

Diversity and hierarchy. During different stages of learning, students' learning task is different from learning objectives to cognition, the senior and junior students need pay attention to apply their knowledge that have certain professional skills. Therefore, the design of practice teaching activity need according to the characteristics of different grade, and put forward different practical teaching targets. Low-grade students can enhance the cognition of practice teaching, the understanding of 
enterprise human resource management; high grade students should enhance participation in the practice of human resource management and form a certain actual ability to work.

Initiative. In the practice teaching in the major position, students need to find the problem, and seek their own answers. Guidance of teachers is only heuristic counseling to help students think correctly. In the practice teaching of the organization, teacher should emphasize on the active participation of the students and pay attention to the students' performance in various practical activities.

\section{Exploration of Practical Teaching of Human Resource Management Major}

Changing concept, paying attention to the function of practical teaching in the cultivation of human resource management major talents. The main performance in the teaching plan of professional practice teaching hours allocated slants little, lack of effective monitoring and evaluation measures of practice teaching process and results, practice teaching base and the construction of infrastructure, not perfect. In addition, practice teaching of liberal arts is not as operable as science and engineering, and it is more abstract and natural to be ignored. Colleges and universities should re-examine and scientific human resource management professional location aware, personnel training target, train students' ability to focus, emphasis on imparting knowledge and cultivating the ability of combination and the integration of theoretical teaching and practical teaching, commonality education and individuality development combined, and strive to cultivate has a certain theoretical basis and full of innovative spirit and a strong ability to innovate human resource management of senior specialized talents. This is the basic prerequisite for the development of human resource management, and the power and the source of promoting the reform of the practical teaching of human resource management.

Establish and improve the practical teaching management system of human resource manage ment major. System has a role in leading and norms, according to their own actual for serious research and exploration, the school should establish and perfect the human resource management practice teaching management system, give play to the role of lead and standardize the system, and make the practice teaching into the orbit of the benign operation towards a more scientific, standardized direction. To establish a sound and effective incentive system, lead the outstanding teachers to take the initiative to assume human resource management practice teaching tasks, exploration and practice of teaching rules and carry out the research and reform of the practice teaching, and improve the teaching quality of human resource management practice. Establish and improve the practice teaching quality assurance and monitoring mechanism, the guidance and practical guidance and other aspects of the formulation standard and method of assessment, and ensure the standardization and scientific process of teaching practice. Establish the protection system of practical teaching, and ensure the smooth implementation of practical teaching from the teachers, funds and other aspects.

Building a high level and stable practice teaching team of human resource management major. Practice of teachers is to improve the human resource management practice teaching quality security personnel. Therefore, researchers should take strong measures to increase the intensity of the construction of practice teaching team, construction of a high level of stability of the human resource management practice teaching team. In accordance with the principles of introduction and culture, combined with full-time and part-time, increase the number of human resource management practice teaching, the teachers; to encourage, support and leading to high level teachers engaged in teaching 
practice of human resource management, improve the quality of teachers in teaching practice; formulate corresponding policies, implement incentive to make outstanding achievements in teaching practice of teachers, and improve the enthusiasm of the teachers' practice. In light of the present situation of the human resource management, professional teachers practice lack the ability to consider the teachers' participation in the enterprise practice or management activities, and enterprises should carry out horizontal subject cooperative research, so as to improving teachers' practical teaching skills and level.

Establish a modern human resources professional skills training system. Develop the laboratory construction of human resource management and make practical teaching platform of specialized laboratories. By integrating laboratory teaching with other teaching resources, the teaching contents in the teaching of the whole process, the teaching process will be significantly easier, so that students can make the specific experimental breakthrough over the limitation of space and time, enhance the learning experience and meet the operating requirements, and greatly improve the innovation ability, learning ability and practice ability.

Establish a stable external practice base for human resource management major. Schools and colleges should give full play to the role of foreign contacts, make extensive use of the influence of the government, enterprises and institutions and the relationship between the alumni, through cooperation and the establishment of the school run enterprises and other forms of establishment of out of school practice teaching base, but also enhance the visibility of the school in the society, in order to achieve the purpose of enrollment and employment. Use of opportunities for winter and summer vacations and curriculum practice by teachers or school links outside enterprises to carry out field visits, short time study although not in-depth business procedure, but can enable students to the enterprise's operation form a preliminary understanding, enables them to learn the theoretical knowledge and practical combination, for future study and practical operation and lay a good foundation.

Strengthen the practical teaching management of human resource management major. Practice teaching quality monitoring system, combined with the production practical arrangements and organizational practice teaching, as far as possible to avoid the student is too concentrated, enterprises cannot afford the embarrassing situation; to make full use of cold summer vacation to organize students social investigation and practice in a planned way, to increase the student's perceptual knowledge; to careful arrangements for professional practice, professional practice as much as possible to choose the relatively high level of human resource management of enterprise practice, in order to avoid internship students scattered, teachers guide difficult problems; to reform the teaching link of graduation practice. Graduation thesis should as far as possible also it puts forward measures or programs to solve practical problems in human resource management.

\section{Acknowledgment}

This work was supported by Jiangxi Province Office of Education of Humanities and Social Science Research [No. GL 1409]. And the project of Technology Department of Jiangxi Province [No 2013BBE50051] also gives us lots of help. The author thanks Dr. Hu Jian-feng for help. 


\section{References}

[1] Liu C Y. Innovation of Teaching Mode for the Major of Human Resource Management[J]. Journal of Shanxi Youth Vocational College, 2014.

[2] Li K. Exploration and Thinking of Higher Vocational Secretary Major of Human Resource Management Course Teaching Reform[J]. Guide of Science \& Education, 2013.

[3] Jiang X R, Li J L. Practical Teaching Problems and Countermeasures in the Major of Undergraduate Human Resource Management[J]. Communications in Computer \& Information Science, 2011.

[4] Wang F X. Construction of Experimental Teaching System for Human Resource Management[J]. Journal of Langfang Teachers College, 2012.

[5] Jian-Ping H U. Studies on the Teaching and Learning of the Human Resource Management Oriented by "Production, Learning, and Researching"[J]. Journal of Guangxi Teachers Education University, 2009.

[6] Elkins T J. Academic internships with the Equal Employment Opportunity Commission: an experiential approach to teaching human resource management.[J]. Sam Advanced Management Journal, 2002, (June).

[7] Zhu L, Yang X. Reflection on the Construction of Human Resource Management Major of Vocational Colleges[J]. Journal of Wenzhou Vocational \& Technical College, 2012.

[8] Steyn G. CREATING KNOWLEDGE THROUGH MANAGEMENT EDUCATION: A CASE STUDY OF HUMAN RESOURCE MANAGEMENT[J]. Education, 2003.

[9] Zhou Z, Wu H, Lei X. Reform of Practice Teaching in the Speciality of Human Resource Management in Local Colleges[J]. Journal of Xiangnan University, 2012.

[10] Luo F, Ang L I, Peng Q. Research on the Practice Teaching Reform of Human Resource Management Based on Employment[J]. Higher Education Forum, 2009. 